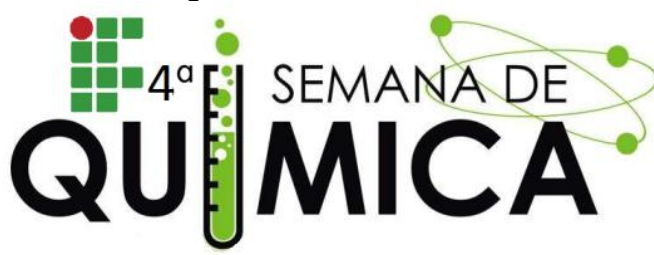

\section{CARACTERIZAÇÃO MICROBIOLÓGICA DA ÁGUA UTILIZADA PARA A IRRIGAÇÃO DAS HORTAS COMUNITÁRIAS NO MUNICÍPIO DE NOVA CRUZ-RN}

\author{
PEREIRA, A. H. D. S. (IFRN-NC); SANTIAGO, A. F. J. (IFRN-NC); SILVA, A. C. O. (IFRN-NC)
}

Palavras Chave: água, coliformes, horta comunitária

\section{INTRODUÇÃO}

Como consequência do crescimento vertiginoso das atividades urbanas $e$ agropecuárias, há indicativos de que a qualidade da água pode ser comprometida $[\ldots]^{[1]}$.

A presença de contaminantes biológicos que podem estar presentes na água utilizada para irrigação. $O$ estudo objetivou-se avaliar a qualidade da água, através dos parâmetros microbiológico.

\section{METODOLOGIA}

Foram coletadas três amostras do poço, utilizando frascos plásticos estéril, continha tiossulfato (inibidor de cloro) e foram realizadas as analises microbiológicas (coliformes totais/Termotolerantes) baseado no método do substrato cromogênico, adotada pela praticidade, facilidade e custo/benefício.

\section{RESULTADOS E DISCUSSÕES}

Os dados das análises microbiológicas da água são apresentados na tabela 1.

Tabela 1 - Resultados (presença/ausência) dos coliformes totais e termotolerantes

\begin{tabular}{|c|c|c|}
\hline $\begin{array}{c}\text { Parâmetro } \\
\text { microbiológico }\end{array}$ & $\begin{array}{c}\text { Coliformes } \\
\text { totais }\end{array}$ & $\begin{array}{c}\text { Coliformes } \\
\text { Termotolerantes }\end{array}$ \\
\hline Amostra 001 & $\mathrm{x}$ & $\mathrm{x}$ \\
\hline Amostra 002 & $\mathrm{x}$ & $\mathrm{x}$ \\
\hline Amostra 003 & $\mathrm{x}$ & $\mathrm{x}$ \\
\hline
\end{tabular}

Observa-se que todas as amostras apresentaram presença de coliformes termotolerantes, fato confirmado com os dados da confirmação da presença de coliformes totais em todas amostras.

A Resolução vigente não coloca limites para coliformes totais, sendo permitida a presença dos mesmos. Já para coliformes termotolerantes, estabelece o NMP máximo permitido de 200 coliformes por $100 \mathrm{~mL}$, em $80 \%$ ou mais de pelo menos seis amostras ${ }^{[2]}$.

\section{CONCLUSÃO}

Em relação ao laudo microbiológico é importante o monitoramento com análises mais criteriosas, conforme a Resolução $n^{\circ} 357$ do CONAMA exige, não abordado nessa trabalho, e sendo de total importância para avaliar a qualidade da água usada para fins de irrigação.

\section{REFERÊNCIAS}

${ }^{1}$ RESENDE, A.V. Agricultura e Qualidade da Água: Contaminação da Água por Nitrato. Planaltina: Embrapa Cerrados, 2002.

2 CONSELHO NACIONAL DO MEIO AMBIENTE [CONAMA]. Resolução $n^{\circ} 357$ de 17 de Março de 2005. Dispõe sobre a classificação dos corpos de água e diretrizes ambientais para o seu enquadramento, bem como estabelece as condições e padrões 27 de lançamento de efluentes, e dá outras providências. [S.I.: s.n.], 2005. 